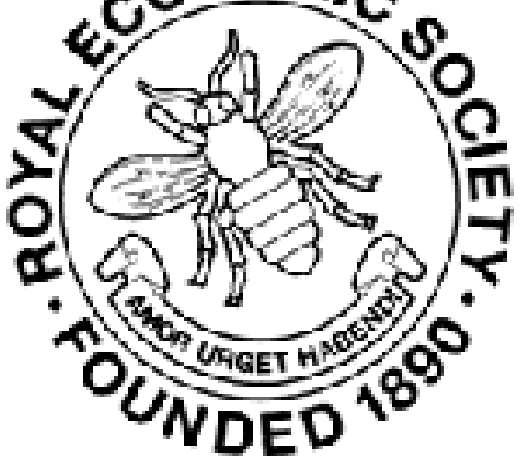

\title{
WILEY
}

The Labour Insurance Law in Hungary

Author(s): Menyhért Szántó

Source: The Economic Journal, Vol. 18, No. 72 (Dec., 1908), pp. 631-636

Published by: Wiley on behalf of the Royal Economic Society

Stable URL: http://www.jstor.org/stable/2220648

Accessed: 27-06-2016 02:54 UTC

Your use of the JSTOR archive indicates your acceptance of the Terms \& Conditions of Use, available at

http://about.jstor.org/terms

JSTOR is a not-for-profit service that helps scholars, researchers, and students discover, use, and build upon a wide range of content in a trusted digital archive. We use information technology and tools to increase productivity and facilitate new forms of scholarship. For more information about JSTOR, please contact support@jstor.org.

Royal Economic Society, Wiley are collaborating with JSTOR to digitize, preserve and extend access to The Economic Journal 
or even heard of Sir M. Decker's Essay on the causes of the Decline of Foreign Trade, till I found it quoted in your essay." But this renders still more important the withdrawal by Tucker in the next edition of the "Brief Essay on Trade" (1753) of any reference to Decker as the author of the tract in question. Under the circumstances, the omission of what was definitely stated three years before certainly seems to indicate the discovery and correction of a mistake. Postlethwayt, however, attributes the work to Decker in the "Universal Dictionary of Trade," in the editions of both 1751 and 1774, and also in "Great Britain's True System " in 1757.

The matter seems much as follows. About the time of Decker's death, there was for some reason or other a belief current that the work in question was due to him. As evidence of this, we have the Dublin edition, and the references by both Postlethwayt and Tucker, the latter of whom, at any rate, was not affected by the Dublin title-page, since he was referring to the quarto edition of 1744. In a year or two, however, Tucker sees reasons for abandoning this ascription, while Fauquier, who in his first edition makes no mention of any author, in his second and third editions attributes the work to Richardson.

Whether the work was by Richardson is difficult to determine; that rests mainly on Fauquier's testimony. But, leaving this aside, in the lights of the facts given above, certain conclusions seem well-established, namely :-

(1) That it was not by Decker.

(2) That it was not by the author of "Serious Considerations."

(3) That the author was alive in $\mathbf{1 7 5 0 .}$

E. C. K. Gonner

\section{The Labour Insurance Law in Hungary.}

KEEPING pace with industrial improvement Hungary is trying to establish effectively all those institutions' for the protection of workmen which are necessary to peaceful social evolution. A notable manifestation of this endeavour was the passing of Act XIX. of 1907, treating of the insurance of industrial and commercial employés against illness and accidents. We should like to make the reader acquainted with the antecedents, principles and chief provisions of this Act as briefly as possible. 
The ideas which led Germany in the 'eighties to a stupendous extension of institutions in connection with labour insurance took a lively hold also on the Hungarian Parliament.

In 1884, whilst discussing the industrial Bill, the House called upon the Government to draft a Bill for the insurance of workmen against accidents. The manufacturers were obliged by the industrial law itself to adopt and maintain in their factories at their own cost such measures as were necessary for the security of the workman's life and health. The same Act also encouraged industrial employees to found aid funds, and declared that where the majority of the employees decides to found an aid fund, the minority is also bound to join and to pay a certain percentage of their weekly wages for the maintenance of the fund.

Under the influence of a great mining catastrophe in 1885 Par liament declared the necessity for a law providing for the security of the workman's life and health, and also for the surviving dependants of workmen killed by accident.

The first Bill of this kind, entitled " Sick Benefits for Industrial and Factory Employees," was brought in by the Board of Trade in 1891, and soon became law. From lack of practical experience, this law followed the form of organisation existing in Germany and Austria : entrusting the insurance to district sick clubs, at the same time allowing sick funds to be founded by workmen of the same guild, by employers in their own factories, and also by private societies. The preamble of the Sick Benefit Bill promised the speedy introduction of a Bill for accident insurance; in the meanwhile sickness or cases of fatal accidents were attended to by the sick benefit funds.

The great number of the sick funds led to the dissipation of their strength, so that some of them were not capable of performing the task laid down for them by the law.

In the meanwhile the law treating of factory inspection, enforcing Government supervision of factories and industrial establishments, thereby taking the necessary measures for the physical protection of workmen, was framed in 1893.

Several plans were drafted by the Board of Trade for insurance against accident. These, however, were never carried into effect.

Public opinion felt more and more the necessity of this kind of insurance; as an example of this we may take the practice of the courts of justice which, in reference to the supervision law of 1893, demanded more and more urgently from the employers compensation for the workmen or their surviving dependants in cases of accidents happening during employment. This compen- 
sation often reached a very substantial sum. Private insurance societies were by these means brought into a flourishing condition, as the employers transferred their liability to the insurance societies by means of a yearly payment. On the other hand, in the more dangerous trades, the masters themselves expressed a wish for legally defined accident insurance.

Before the accident insurance of industrial workers (on account of the difficulties of the work and the many sides of the question) could be properly worked out and carried into effect, a Bill was brought in by the Board of Agriculture to provide in some measure in cases of accident for agricultural labourers, the number of whom in Hungary considerably exceeds that of those employed in trades. This Bill passed into law as Act XVI. of 1900, and a fund was formed, chiefly by the State, for agricultural labourers and servants.

Employers are bound to pay into the Fund 1.20 "krone" (1s.) annually for each servant employed by the year; the membership of other labourers is voluntary. The fund assists any of its members thrown out of work through accident; in cases of incapacity not caused by accident, those are assisted who have been members of it for at least ten consecutive years. If the member loses more than a week by accident, over and above the expenses of the doctor and of medicine, he receives one "krone" (10d.) daily, but only during a period of sixty days. A totally disabled labourer receives ten "krone" (8s. 4d.) a month as long as he lives. If the accident ends in death the Fund pays 100 "krone" (£4 3s. 4d.) for funeral expenses, but if there are dependant survivors, a contribution of 400 "krone" (£16 13s. 4d.).

A new Act (XIX. of 1902) made the insurance of those employed on threshing and cutting machines obligatory at the expense of the farmers.

In 1902 the Minister of Commerce organised a special department for the codification of social politics, the first task of which was the drafting of a Bill for obligatory insurance against accidents. In the following year the Bill was ready, and, with the purpose of inviting public criticism, it was published in two volumes containing an extensive and precise report of arguments and a collection of materials referring to every branch of the question. The interest of the expert public was a very lively one; the Bill, however, was unable to reach the stage of Parliamentary discussion owing to the political situation of the time.

As soon as a new Government was formed in 1906, the Minister of Commerce considered it as one of his first tasks to work out 
the whole complication of the workmen's insurance laws. As the necessity to modify the sick benefit law became ever more pressing, in the same year the Board of Trade had a Bill drafted for the common organisation of sick benefit and accident insurance, taking the former plan as a basis. The Bill having been discussed by many experts, was accepted by the Legislature in 1907 (Act XIX.), brought into working on July 1st, 1907, and is based on the following principles :-

(1) Insurance for sick benefit is obligatory on all employees in every branch of trade and commerce whose salary does not exceed 2,400 "krone" (£100) a year, or eight "krone" (6s. 8d.) a day; on the other hand, insurance against accident is obligatory in every dangerous employment mentioned in the law, without regard to amount of salary, but in the question of compensation a salary of not more than 2,400 "krone" (£100) is taken into consideration. (2) Sick benefit and accident insurance are entrusted to the same funds, which are united into one central fund for the whole country. (3) In the Central National Fund, as well as in its local organs, both interested classes-employers and employees-are equally represented. (4) For the decision of disputed questions a select jury is organised.

Insurance for sick benefit has a wider circle, as insurance against accident is not compulsory for workmen employed in some less dangerous small trades, and also is not obligatory for the employees in commerce. Sick benefit consists in doctor's attendance and medicine, including treatment in a sanatorium or watering-place, and of provision for maintenance. Claims on the sick benefit fund cannot be limited to a period of less than twenty weeks, but the Fund can extend this term to a year. A woman in childbed-if she is not otherwise ill-has a claim for sick benefit for six weeks. All members of the family living in the same household are granted treatment free of charge.

Maintenance money equals half of the general wages of the insured employee, but it can be raised until it equals two-thirds of the wages. In case of death a sum equal to 20-40 times the daily wages is given for funeral expenses.

In case of accident, assistance is granted for the first ten weeks by the sick benefit fund; later on the case is supported by the accident insurance fund.

The injured workman during the time of his incapacity receives a pension. If he entirely loses his capacity for work, 60 per cent. of his yearly wages is granted to him; but if besides 
this he becomes impotent and needs constant nursing, the pension is to be raised to 100 per cent.

In case of the death of an injured workman, funeral aid is given up to the sum of twenty times the daily wage; the widow gets a pension of 20 per cent. of his yearly wages; each of the fatherless children 15 per cent., but if also motherless, 30 per cent. ; his parents, grandparents, or orphan grandchildren 20 per cent.; but the total sum of all these payments cannot exceed 60 per cent. of the yearly earnings of the injured workman.

From a humanitarian point of view the Hungarian workmen's insurance law has made a considerable innovation, in which it is a pioneer to the Legislatures of all Europe, for the Hungarian law does not make any difference in the value of the claim on assistance, whether the illness or accident be occasioned by intemperance or by any other cause; in one case only the workman is deprived of his claim, i.e., if he brings about the accident purposely. But even in this case, if death ensues, his family gets the assistance and payments provided by law.

The expenses of the sick benefit fund are borne equally by the employers and the employees, those of accident insurance only by the employers. The premium of the sick benefit funds cannot be fixed under 2 per cent., or over 4 per cent. of the average daily wage; the amount of the premium is fixed by the Central National Fund. In small trades, where the usual number of employees does not exceed five, the premium of the sick benefit fund must not be higher than 2 per cent. during the first five years of the law's working.

As we said, the expenses of accident insurance are borne only by the employers. In order that single trades may contribute to the expenses in the proportion in which they make claims upon the fund, the law prescribes that the insured branches and trades are to be classified according to their danger and according to their obligation to pay the premiums. This classification of danger is not a constant one, but will be modified in time according to the results of experience. As soon as the Central National Fund began to work, the "State Workmen's Insurance Office" prepared the first table of the classification of danger, on the basis of our hitherto very deficient experience, and from the data of foreign insurance societies. The first classification of danger is to be modified as soon as the number of accidents in the different trades makes it advisable; indeed, the National Central Fund is compelled every five years to revise the danger-classification, and, if necessary, to correct it. 
Even within the same trade there may be an individual classification according to the more or less careful provision made by the employer. Therefore it is in the interest of the employers that their own establishments, as well as others of the same trade, should possess every appliance for the protection of workmen.

The provisions of the law for preventing accidents are considered by many experts as a more important measure than the material compensation of the injured workman and of his family, and so, during the occasion of the Parliamentary discussion of the subject, the Government declared its intention to take great care for the protection of the workmen's physical soundness and health.

The insurance for both sick benefit and accident is provided for by the National Sick Benefit and Accident Insurance Fund; its local organs are the District Funds. Besides these, the law has left untouched the funds of the old establishments, but only for the purposes of sick benefit; insurance against accident is also in these cases discharged by the District Funds. All other forms of the previous sick benefit insurance are stopped, whereby their number has been diminished to one-third. So, their power being concentrated, their capacity has been raised.

The National Workman's Sick Benefit and Accident Insurance Fund is an autonomous corporation governed by an equal number of representatives of the insured workmen and of their employers. Over all the workmen's insurance funds there is the State Workmen's Insurance Office to superintend and control them, its expenses being borne by the State.

The law in question provides the greater number of trade employees with the most necessary requirements of life in the two most frequent cases of incapacity for earning : in the cases of illness and accident. On the occasion of bringing in the Bill, the Minister of Commerce announced his intention to draft a Bill for Old Age Pensions and Sick Insurance of Labourers in a short time. If this plan should also succeed, the workman's insurance in Hungary will be the first to realise the object aimed at by all the leaders of workmen's insurance institutions, i.e., to build up all kinds of insurance on a common basis, and to provide for the fulfilment of all its tasks by the same organisation.

MENYHÉRT SzÁNTó,

Director of the Hungarian Institute of Social Service. 